radium. Probably a real satisfaction in his lifebetrayed in unguarded moments - was the success attending his share in the effort to procure radium for the Liverpool Radium Institute and Hospital for Cancer and Skin Diseases.

During the War, Johnstone's work on the dietetic value of fishes gained him an effective position on the Fish Preservation Committee of the Food Investigation Board of the Department of Scientific and Industrial Research.

In 1919, Johnstone was appointed lecturer in oceanography at the University of Liverpool and a year later he succeeded Sir William Herdman to the chair. In this new capacity he was fortunately able to indulge his leaning towards scholarship and philosophy. His works on oceanography brought up to date our knowledge of the physical features of the oceans ; at the same time the story of the origin of the oceans is treated in a manner of fascinating interest to the students of geography and geology ; "A Study of the Oceans" is indeed a new approach to the study of geography in a wide sense. Along with this work he undertook as director the reorganisation of the Port Erin Marine Biological Station and effected great improvements.

In later life the totality of the relations between things became to our savant-as to many other older scientific workers - of greater interest than lesser relations. He had already in 1914 surveyed the "Philosophy of Biology" and had stated the problems in his usual clear manner. These he elaborated later in "Mechanism of Life", and made what proved to be a final contribution recently in "Essentials of Biology" (1932). Here the fundamental problems of biology are discussed simply and logically with a rare clarity and impartiality. On the problem of the origin of life he refines his views of 1914 to the simple statement that ". . . it may be the case that the problem is only a pseudo one and that it is just as foolish to inquire into the origin of life as it would be to ask what was the origin of the universal tendency to entropy increase. We have no doubt that the distinction between living and lifeless things is a problem for physics [present writer's italics]. We have no confidence that the basal conceptions of physics have been established. That being so, it is futile further to continue this discussion".

On this problem-as on many others-the philosopher and research worker discloses the apparent inadequacies of present-day knowledge. In this way James Johnstone leaves his problems and work to posterity, with a satisfying and rare record of achievement; and better still, he leaves a memory of a loveable man, wise and humble, great and unassuming.

\section{Prof. C. M. Thompson}

Claude Metrord Thompson, emeritus professor of chemistry of the University College, Cardiff, was born at Bridgwater in 1855, and was the son of Alexander and Eleanor Thompson. He died at Cardiff on January 4, 1933, at the age of seventy-seven years. Some of the following particulars of his career are from the Western Mail. Prof. Thompson was educated at University College, London; Trinity College, Cambridge, where he was a scholar; and the University of Bonn. At Cambridge he obtained the degree of M.A. ; his D.Sc. was awarded to him by the University of London, which university also bestowed upon him a gold medal for distinction in his subject; and the University of Wales conferred upon him the degree of D.Sc. (honoris causa) for his services during and after its institution in 1893. He was the last of the original professors appointed in 1883 when the University College, Cardiff, was opened under the principalship of Viriamu Jones, and he retired from the service of the College in 1921, with the title of emeritus professor, after a successful career as professor of chemistry.

Dr. Thompson's assistance and advice to the University and the University College were particularly useful regarding the details of educational organisation and in the preparation of regulations, courses, and schemes of study for degrees. Up to the time of his death he was a member of the Court of Governors of the College, appointed by the Chancellor of the University of Cambridge. He found time to carry on research work, particularly into the constituents and possible uses of rare earths and their application to commercial products, such as incandescent mantles.

Dr. Thompson was a generous supporter of the University College at Cardiff, and the donor of many volumes and publications on chemistry to its library. In his early days he found his chief enjoyment in mountaineering during vacations; he was a member of the Alpine Club. He identified himself with local interests by becoming a member of the Cardiff Naturalists' Society, in the work of which he was particularly active. He took a keen delight in gardening, and many of the amenities to be found in "Cae Syr Dafydd", one of Cardiff's parks, are largely due to his care and attention.

A. A. R.

WE regret to announce the following deaths:

Mr. T. H. Coward, a well-known naturalist and an authority on British birds, on January 29, aged sixty-six years.

Sir Percy Sargent, C.M.G., formerly surgeon to St. Thomas's Hospital and the National Hospital, Queen Square, London, and Hunterian professor of surgery and pathology at the Royal College of Surgeons in 1928, an authority on brain surgery, on January 22, aged fifty-nine years.

Dr. John Thomas, joint managing director of the Dyestuffs Group of Imperial Chemical Industries, Ltd., a well-known authority on dye-stuffs, on January 18, aged forty-six years. 